\title{
Chironomids (Diptera, Chironomidae) of the Franz Josef Land archipelago (Arctic Russia)
}

\author{
Andrey B. Krasheninnikov' and Maria V. Gavrilo
}

Krasheninnikov AB and Gavrilo MV. 2014. Chironomids (Diptera, Chironomidae) of the Franz Josef Land archipelago (Arctic Russia). Fauna norvegica 34: 1-6.

The first data on the chironomids fauna of the Franz Josef Land archipelago belong to M. Goetghebuer (1933). He noted 16 adults males Hydrobaenus conformis (Holmgren, 1869). In the present study, three new species (Diamesa (Diamesa) arctica (Boheman, 1865), Limnophyes pumilio (Holmgren, 1869), Tokunagaia rectangularis (Goetghebuer, 1940)) and one new subfamily (Diamesinae) are recorded in the Franz Josef Land archipelago bringing the chironomid fauna in this archipelago to a total of seven species from two subfamilies.

doi: 10.5324/fn.v34i0.1665. Recieved: 2014-02-19. Accepted: 2014-11-09. Published online: 2014-12-19. ISSN: 1502-4873 (printed), 1891-5396 (electronic).

Keywords: Chironomidae, biodiversity, the Franz Josef Land archipelago, Arctic Russia

1. Perm' State University, Bukireva str., 15 Perm 614990, Russia

2. National Park "Russian Arctic", Sovetskikh Kosmonavtov ave. 57, Arkhangelsk 1630161, Russia

Corresponding author: Andrey B. Krasheninnikov

E-mail: krasheninnikov2005@yandex.ru

\section{INTRODUCTION}

The Franz Josef Land archipelago is a compact group of 192 islands, which are located in the northern part of the Barents Sea on the edge of the continental shelf some $800 \mathrm{~km}$ from the nearest mainland, the north-west Taimyr Peninsula, Siberia. The archipelago has a relatively small span: from west to east $375 \mathrm{~km}$, from north to south $-234 \mathrm{~km}$. It is the most glaciated area within Eurasian Arctic with $85 \%$ of the area covered by ice (Grosswald et al. 1973). The archipelago lies within the Atlantic region of the Arctic climatic zone, its climate is typically maritime. The average annual temperature is -11.0 to $-12.0^{\circ} \mathrm{C}$. Summer is short and cool with average monthly temperatures exceeding zero $\left(+0.2\right.$ to $\left.+1.1^{\circ} \mathrm{C}\right)$ observed in July and August. Sub-zero temperatures can occur throughout the year. High winds (over $15 \mathrm{~ms}^{-1}$ ) are recorded for 56 to 84 days a year (Vassiliev 2013). Summer seasons of the study years were relatively warm with mid-summer air temperatures averaged within +0.9 to $+1.3^{\circ} \mathrm{C}$, peaked at 4 to $5^{\circ} \mathrm{C}$ in July-August (data of the Krenkel weather station on Hayes Island, http://www. rp5.ru).
The vegetation of Franz Josef Land refers to a polar desert type (Alexandrova 1983) with cryptogam, herb barrens and grass, forb, cryptogam tundra complexes defined (CAVM 2003). Plant cover is sparse (less than $40 \%$ ) and very lowgrowing in dry and wet barrens with few vascular plant species among bryophytes and cryptogamic crusts, or moderate (40$80 \%$, in some favorable places up to $100 \%$ ) in moist habitats where more diverse grasses, forbs, lichens and mosses are common and more developed.

Remote high-Arctic areas are difficult to access and knowledge of their biodiversity is rather incomplete, mostly in terms of easily recordable species such as birds, mammals, or vascular plants. Terrestrial invertebrates are often overseen even in more detailed studies in spite of their importance for land ecosystems functioning. Among other Arctic islands, the Franz Josef Land has an extreme lack of knowledge on terrestrial invertebrate fauna diversity (Coulson et al. 2014). Conservation status of the archipelago, which is designated as a special purpose reserve since 1994, puts collection of the biodiversity data on different taxa as a priority task. 
Table I. List of stations giving locality data where chironomids species were found during this study.

\begin{tabular}{|c|c|c|c|}
\hline Date & Station & Locality & Latitude and longitude \\
\hline 17.VIII.2012 & 1 & Alger Island, Cape Podgornyi & 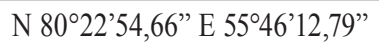 \\
\hline 14.VIII.2013 & 2 & Alger Island, Cape Podgornyi & N 80²2’55,2” E 5546’11,2” \\
\hline 21.VIII.2013 & 3 & Bell Island, Nielsen Bay & N 8002’11,6” E 49¹2’57,2” \\
\hline 12.VIII.2012 & 4 & George Land, Krauter Cape & 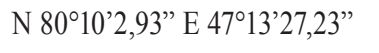 \\
\hline 13.VIII.2012 & 5 & George Land, south coast between Niel and Krauter capes & N 80¹5’7,92” E 46'54'22,90” \\
\hline 9.VIII.2012 & 6 & Hayes Island, nearby Krenkel weather station & N 80³7’51,67”' E 587’41,23” \\
\hline 3-7.VIII.2012 & 7 & Hooker Island, Tikhaya Bay & 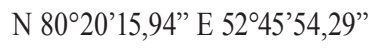 \\
\hline 4.VIII.2013 & 8 & Hooker Island, Tikhaya Bay & N 80²0’10,3” E 5246’32,9” \\
\hline 2.VIII.2013 & 9 & Hooker Island, Rubini Rock & N 80¹9’2,7’" E 52॰51’4,5” \\
\hline 22.VIII.2012 & 10 & Mabel Island, Konrad Cape & N $80^{\circ} 01^{\prime} 38,35^{\prime \prime}$ E $49^{\circ} 20^{\prime} 2,15^{\prime \prime}$ \\
\hline 21.VIII.2013 & 11 & Mabel Island, Konrad Cape & N 8001’9,4” E 49²1’28,5” \\
\hline 5.VIII.2012 & 12 & Ziegler Island, Meshok Bay & N 810.'0,73" E $56^{\circ} 17^{\prime} 41,89^{\prime \prime}$ \\
\hline
\end{tabular}

The first data on the chironomid fauna of the Franz Josef Land archipelago were presented by M. Goetghebuer (1933). He noted 16 adults males of Hydrobaenus conformis (Holmgren, 1869), which were collected on August 17, 1930 on the Bell Island. Further investigations were continued by A.B. Krasheninnikov and M.V. Gavrilo (2012) almost eighty years later.

This study focuses on non-biting midges, family Chironomidae, which is known to be one of the most species rich and abundant groups of amphibiotic arthropods at high latitudes. New data on distribution of chironomids contributes to our knowledge on global biodiversity patterns and is important for better understanding of their evolution and adaptations to different environmental conditions.

\section{MATERIAL AND METHODS}

The material for this study was collected during August of 2012 and 2013 at 12 sites in the Franz Josef Land archipelago (Table 1). Chironomids were either sampled manually from the vegetation and water surface of small ponds (in 2012), or by means of sweep nets from developed vegetation patches (in 2013). All insects were collected in warm weather with air temperatures of $+4-+6^{\circ} \mathrm{C}$ (our local measurements) and mostly during calm days. The material was preserved in Oudemans' solution and later mounted on slides in sandarac medium (Krasheninnikov 2011). Specimens are deposited in the collections of the Perm' State University, Chironomids collection (Diptera, Nematocera, Chironomidae) of Krasheninnikov Andrey Borisovitch (CCK).

The publications of Halvorsen and Sæther (1987), Lundström (1915), Makarchenko (1998), Makarchenko and Makarchenko (2007, 2009), Sæther (1976, 1989, 1990, 1995 and 2004) were used for identification of collected chironomids.

\section{RESULTS}

The following is an annotated list of species that have been found by us on the archipelago.

Subfamily Diamesinae

\section{Diamesa (Diamesa) arctica (Boheman, 1865)}

Material examined: CCK 149/1, 1 male imago, station number (stn) 11 .

Distribution: Holarctic arctic-alpine species (Makarchenko 1998).

Remarks: It is a new species to the archipelago.

\section{Subfamily Orthocladiinae}

\section{Chaetocladius (Amblycladius) franzjosephiensis Krasheninnikov, 2013}

Material examined: CCK 146/1, 1 male imago, stn 1.

Distribution: The species is known only from the type locality from Cape Podgornyi, Alger Island, the Franz Josef Land archipelago.

Remarks: A species is closely related to Ch. (A.) subplumosus (Kieffer, 1923) and Arctosmittia biserovi Zelentzov, 2006. It can be easily distinguished from the first species by megaseta and well developed IVo, from the second species by well-developed anal point.

\section{Hydrobaenus conformis (Holmgren, 1869)}

Material examined: CCK 148/8, 1 male imago, stn 3, CCK 148/4, 148/5, 2 male imago, stn 10, CCK 148/9, 1 male imago, 
stn 11, CCK 148/1, 148/2, 148/6, 148/7, 4 male imago, stn 12.

Distribution: Holarctic species: Algeria, Canada, Finland, France, Japan, Lebanon, Norway, Russia (Franz Josef Land archipelago, Urals, Baikal, Far East), Sweden (Ashe, O'Connor 2012; Krasheninnikov 2013).

\section{Limnophyes pumilio (Holmgren, 1869)}

Material examined: CCK 83/1, 1 male imago, stn 8.

Distribution: Holarctic species: Austria, Canada, Denmark, Finland, France, Germany, Great Britain, Greenland, Ireland, Lebanon, Netherland, Norway, Romania, Russia, Sweden, Switzerland, U.S.A. (Ashe, O'Connor 2012; Krasheninnikov 2013).

Remarks: It is a new species to the archipelago.

\section{Metriocnemus (Metriocnemus) eurynotus (Holmgren, 1883)}

Material examined: CCK 90/6, 1 male imago, stn 2, CCK 90/1, 90/2, 90/3, 3 male imago, stn 4, CCK 90/4, 1 male imago, stn 5, CCK 90/5, 1 male imago, stn 7, CCK 90/7, 1 male imago, stn 8, CCK 90/8, 1 male imago, stn 9.

Distribution: Holarctic species: Austria, Belgium, Canada, China, Czech Republic, Denmark, Finland, France, Germany, Great Britain, Greenland, Hungary, Iceland, Ireland, Italy, Japan, Lebanon, Morocco, Netherland, Norway, Poland, Portugal, Romania, Russia, Slovakia, Spain, Sweden, Switzerland, U.S.A. (Ashe, O’Connor 2012; Krasheninnikov 2013).

\section{Metriocnemus (Metriocnemus) sibiricus} (Lundström, 1915)

Material examined: CCK 147/4, 1 male imago, stn 5, CCK 147/1, 147/2, 147/3, 3 male imago, stn 6, CCK 147/5, 1 male imago, stn 9 .

Distribution: The New Siberian Islands, Franz Josef Land archipelago (Krasheninnikov, Gavrilo 2013).

Remarks: All detected specimens are females. Currently, males of this species have not been found in Franz Josef Land.

\section{Tokunagaia rectangularis (Goetghebuer, 1940)}

\section{Material examined: CCK 136/1, 1 male imago, stn 2.}

Distribution: This is a transpalaearctic species: Austria, China, Finland, France, Italy, Mongolia, Norway, Romania, Russia (Urals, Far East), Sweden, Switzerland, Turkey (Ashe, O'Connor 2012; Krasheninnikov 2013).

Remarks: It is a new species to the archipelago. Hypopygium of this specimen is shown in Figure 1.

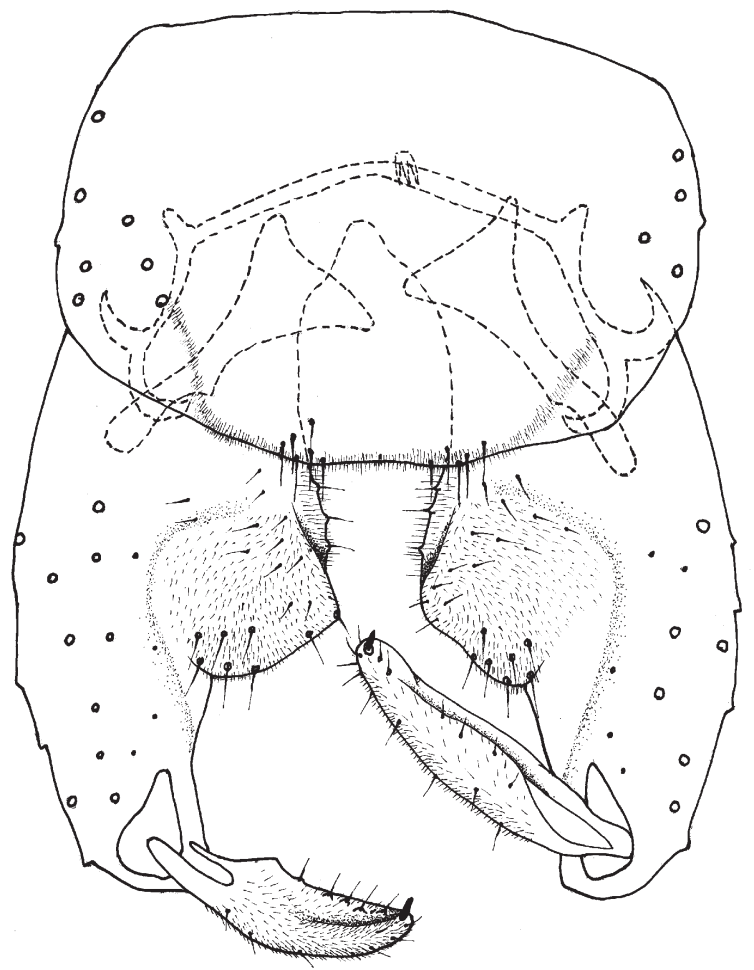

Figure I. Hypopygium of Tokunagaia rectangularis (Goetghebuer, 1940) from the Alger Island.

\section{DISCUSSION}

From the present results the chironomid fauna of the Franz Josef Land archipelago now include a total of seven species from six genera belonging to two subfamilies (Diamesinae and Orthocladiinae). The three species Diamesa (Diamesa) arctica, Limnophyes pumilio and Tokunagaia rectangularis were observed in the study area for the first time. It should be emphasized that chironomids are the only amphibiotic insects from the archipelago known so far. The total number of chironomids is low as compare to the better studied Arctic archipelagos such as Svalbard and Novaya Zemlya, where 63 and 68 species are revealed respectively (Krasheninnikov 2013; Coulson et al. 2014). This reflects a poor state of knowledge but also more severe environmental condition in Franz Josef Land.

Most of the found species are widespread with four species having a Holarctic distribution and one species (Tokunagaia rectangularis) has a transpalaearctic range. The other two species of non-biting midges, Ch. (A.) franzjosephiensis and $M$. (M.) sibiricus, have insular high-Arctic range, with the former being endemic to the Franz Josef Land archipelago.

As for the distribution of other chironomid species on the islands of the Eurasian sector of the Arctic Ocean (Table 2), the $D$. (D.) arctica and L. pumilio are known from the Svalbard, the Novaya Zemlya archipelago and the Wrangel Island; $M$. (M.) eurynotus is found on the Svalbard, the Severnaya Zemlya 
archipelago, the Novaya Zemlya archipelago and the Wrangel Island; H. conformis is recorded on the Svalbard and the Novaya Zemlya archipelago; $M$. (M.) sibiricus was described from the New Siberian Islands only before this study; T. rectangularis is known from the Wrangel Island (Hirvenoja 1967; Makarchenko,
Makarchenko, Vekhov 1998; Makarchenko, Makarchenko 2001; Sæther 2004; Zelentsov 2007).

Occurrence of chironomids within the Franz Josef Land archipelago is also unevenly studied due to poor sampling (opportunistic collection only, and late in the season).

Table 2. The distribution of chironomid species found on the Franz Josef Land archipelago and on the islands of the Eurasian sector of the Arctic Ocean (Krasheninnikov 2013; Coulson et al. 2014).

\begin{tabular}{lcccccc}
\hline \multicolumn{1}{c}{ Islands } & $\begin{array}{c}\text { Franz Josef } \\
\text { Land }\end{array}$ & Svalbard & $\begin{array}{c}\text { Novaya } \\
\text { Zemlya }\end{array}$ & $\begin{array}{c}\text { Severnaya } \\
\text { Zemlya }\end{array}$ & $\begin{array}{c}\text { New Siberian } \\
\text { Islands }\end{array}$ & $\begin{array}{c}\text { Wrangel } \\
\text { Island }\end{array}$ \\
\hline $\begin{array}{l}\text { Diamesa (Diamesa) arctica (Boheman, 1865) } \\
\text { Chaetocladius (Amblycladius) franzjosephiensis }\end{array}$ & + & + & + & - & - & + \\
Krasheninnikov, 2013 & + & - & - & - & - & - \\
Hydrobaenus conformis (Holmgren, 1869) & + & + & + & - & - & - \\
Limnophyes pumilio (Holmgren, 1869) & + & + & + & - & - & + \\
$\begin{array}{l}\text { Metriocnemus (Metriocnemus) eurynotus } \\
\text { (Holmgren, 1883) }\end{array}$ & + & + & + & + & - & + \\
$\begin{array}{l}\text { Metriocnemus (Metriocnemus) sibiricus } \\
\text { (Lundström, 1915) }\end{array}$ & + & - & - & - & + & - \\
Tokunagaia rectangularis (Goetghebuer, 1940) & + & - & - & - & - & + \\
\hline
\end{tabular}

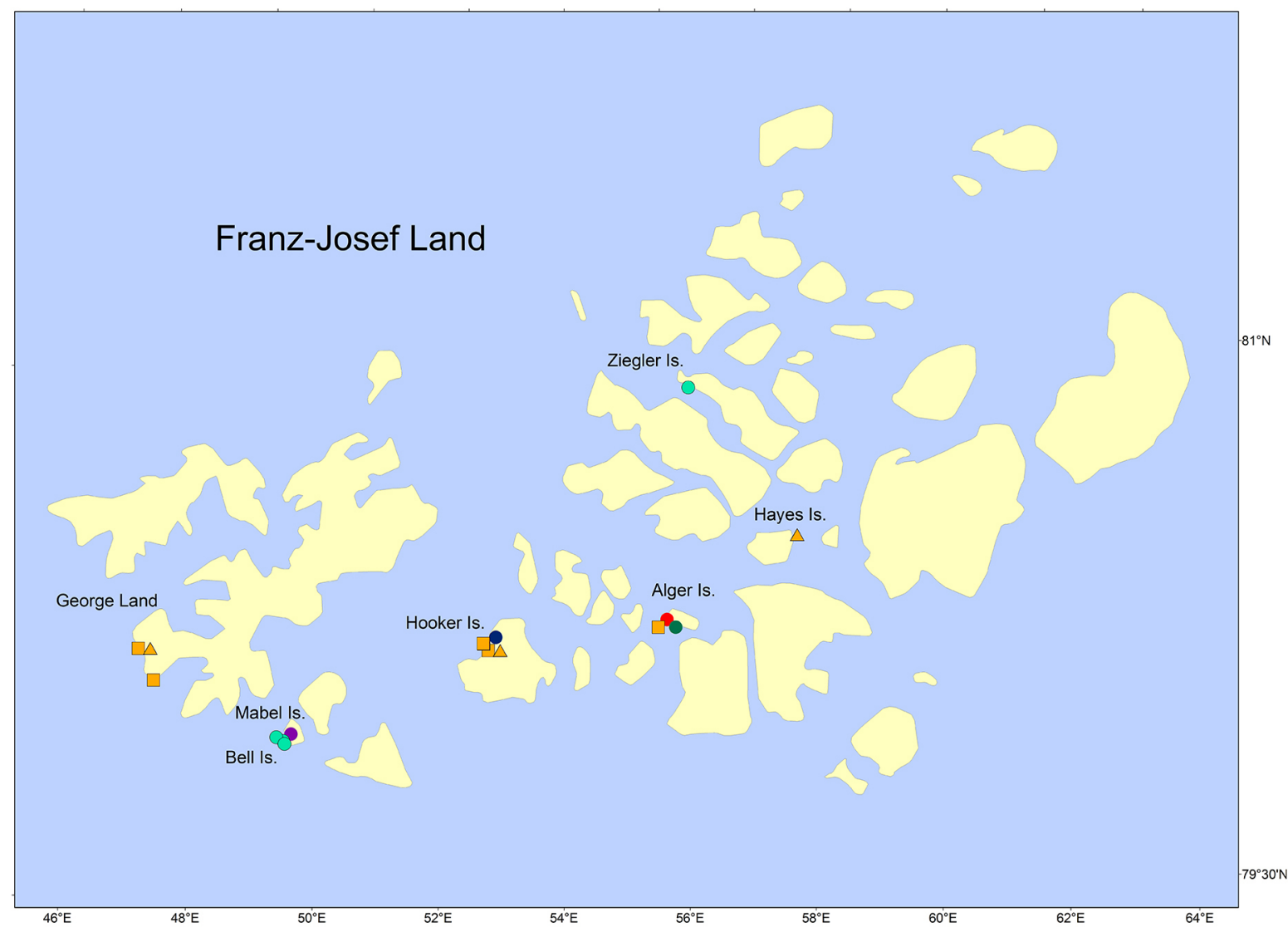

Figure 2. Distribution of chironomids on the Franz Josef Land archipelago: $\bullet$ - Diamesa (Diamesa) arctica; $\bullet-C h a e t o c l a d i u s ~(A m b l y c l a d i u s)$ franzjosephiensis; • - Limnophyes pumilio; $\square-$ Metriocnemus (Metriocnemus) eurynotus; $\triangle$ - Metriocnemus (Metriocnemus) sibiricus; - Hydrobaenus conformis; - - Tokunagaia rectangularis. (The map was compiled on the basis of map sheets U-37,38,39,40 and U-41,42,43,44, which are made Minsk cartographic factory of Main Department of Geodesy and Cartography of the USSR Ministry of Internal Affairs and are printed in 1959). 
There are three species known from the Alger and Hooker islands, two species from the Mabel Island and the George Land, and one species from the Bell, Hayes and Ziegler islands. Localities in the different Islands are shown in Figure 2.

While three species on Hooker Island were collected during two seasons in three different locations/stations with similar habitats (patchy grass-moss moist tundra on the low marine terrace), the two species on Alger Island were collected in the same location with waterlog grass-moss cover during two consecutive years (two stations in table 1). According to current state of knowledge, $H$. conformis is the most widespread and common species of non-biting midges on the Franz Josef Land. In two cases, mass occurences of this species was observed under conditions of air temperature at $+4^{\circ} \mathrm{C}$, no winds, prior to rain with a thunder (Ziegler Island, 2012) or under dense fog (at Bell Island in 2013). Chironomids flocked on attractive surfaces like wooden walls of buildings, white stones, bright cloths etc. up to the observed height of $2 \mathrm{~m}$.

Information on species composition and distribution of chironomids obtained in this study contributes not only to knowledge of the Franz Josef Land biodiversity but also to better understanding of chironomid diversity and distribution through the circumpolar range, it gives background information for further monitoring of insect diversity and species distribution, and possible invasions in high-Arctic under conditions of current climate change.

\section{ACKNOWLEDGMENTS}

The reported study was partially supported by RFBR, research project № 12-04-31143 мол_а. Field work was supported by the National Park Russian Arctic and The National Geographic Pristine Seas Expedition FJL - 2013.

\section{REFERENCES}

Alexandrova VD. 1983. Polar desert vegetation of the USSR. L. $142 \mathrm{p}$ (in Russian).

CAVM Team. 2003. Circumpolar Arctic Vegetation Map. Scale 1:7,500,000. Conservation of Arctic Flora and Fauna (CAFF) Map No. 1. U.S. Fish and Wildlife Service, Anchorage, Alaska. Ashe P, O'Connor JP. 2012. A World Catalogue of Chironomidae (Diptera). Part 2. Orthocladiinae. Irish Biogeographical Society \& National Museum of Ireland, Dublin. 968 pp.

Coulson S.J., Convey P., Aakra K., Aarvik L., Avila-Jiménez ML., Babenko A., Biersma EM., Boström S., Brittain JE., Carlsson AM., Christoffersen K., De Smet WH., Ekrem T., Fjellberg A., Füreder L., Gustafsson D., Gwiazdowicz DJ., Hansen L.O., Holmstrup M., Hullé M., Kaczmarek L., Kolicka M., Kuklin V., Lakka HK., Lebedeva N., Makarova O., Maraldo K., Melekhina E., Ødegaard F., Pilskog HE., Simon JC., Sohlenius B., Solhøy T., Søli G., Stur E., Tanasevitch A., Taskaeva A., Velle G., Zawierucha K., Zmudczynska-Skarbek K. 2014. The terrestrial and freshwater invertebrate biodiversity of the archipelagoes of the Barents Sea; Svalbard, Franz Josef Land and Novaya
Zemlya. Soil Biology \& Biochemistry. 68:440-470.

Goetghebuer M. 1933. Chironomides du Groenland oriental, du Svalbard et de la Terre de François Joseph. Norsk Polarinstitutts Skrifter 53: 19-31.

Grosswald MG, Krenke AN, Vinogradov ON, Markin VA, Psareva TV, Razumeiko NG, Suhodrovsky VL. 1973. Glaciation of Franz Josef Land. Nauka. 310 p (in Russian).

Halvorsen GA, Sæther OA. 1987. Redefinition and revision of the genus Tokunagaia Sæther, 1973 (Diptera: Chironomidae). Entomologica scandinavica. Suppl. 29: 173-188.

Hirvenoja M. 1967. Notes on the arthropod fauna of Spitsbergen. I, 7. Chironomidae and Culicidae (Diptera) from Spitsbergen. Annales Entomologica Fennica 33: 52-61.

Krasheninnikov AB. 2011. Mounting technique of entomological preparations in sandarac medium. Euroasian Entomological Journal. 10(3): 278-279.

Krasheninnikov AB. 2013. Preliminary data on fauna and distribution of chironomids (Diptera, Chironomidae) from Russian Arctic Islands. Bulletin of Perm University. Biology. $1: 32-36$.

Lundström C. 1915. Résultats scientifiques de l'Expédition Polaire Russe en 1900-1903, sous la direction du Baron E. Toll. Section E: Zoologie. Volume II, livr. 8. Diptera Nematocera aus den arctischen Gegenden Sibiriens. Mémoires de l'Académie Impériale des Sciences. Classe Physico-Mathématique. VIII Série 29(8): 1-33.

Makarchenko EA, Makarchenko MA, Vekhov NV. 1998. Preliminary data on the fauna of chironomids (Diptera, Chironomidae) Novaya Zemlya. Novaya Zemlya. Nature, history, archeology and culture. M.1: 262-267 (in Russian).

Makarchenko EA, Makarchenko MA. 2001. Chironomid fauna subfamily Orthocladiinae (Diptera, Chironomidae) Wrangel Island. Reading the memory of prof. V.J. Levanidov. 1:174186(in Russian).

Makarchenko EA, Makarchenko MA. 2007. A review of Tokunagaia Sæther (Diptera: Chironomidae) from the Russian Far East, with the description of four new species. In Andersen, T. (ed) Contributions to the Systematics and Ecology of Aquatic Diptera: A Tribute to Ole A Sæther. The Caddis Press, Columbus, Ohio, 181-192.

Makarchenko EA, Makarchenko MA. 2009. New records of chironomids (Diptera, Chironomidae, Orthocladiinae) in Far East and bordering territories. VI. Hydrobaenus Fries. Euroasian Entomological Journal Suppl. 8(1) 33-50 (in Russian).

Makarchenko EA. 1998. Chironomids of the subfamily Diamesinae (Diptera, Chironomidae) of the Northern Hemisphere (systematics, biology, biogeography). Dissertation of Biological science Doctor. Vladivostok. 493 p (in Russian).

Sæther OA. 1976. Revision of Hydrobaenus Fries, Trissocladius Kieffer, Zalutschia Lipina, Paratrissocladius Zavrel and some related genera (Diptera: Chironomidae). Bulletin of the Fisheries Research Board of Canada 195: 1-287.

Sæther OA. 1989. Metriocnemus van der Wulp: a new species and a revision of species described by Meigen, Zetterstedt, Stæger, Holmgren, Lundström and Strenzke. (Diptera: Chironomidae). Entomologica scandinavica 19: 393-430.

Sæther OA. 1990. A review of the genus Limnophyes Eaton from the Holarctic and Afrotropical region (Diptera: Chironomidae, Orthocladiinae). Entomologica scandinavica 35: 1-139.

Sæther OA. 1995. Metriocnemus van der Wulp: Seven new species, revision of type material and new records (Diptera: Chironomidae). Annales de limnologie 31:35-64.

Sæther OA. 2004. The chironomids (Diptera, Chironomidae) described by Lundström (1915) from arctic Siberia, with 
a redescription of Derotanypus sibiricus (Kruglova and Chernovskii). Zootaxa 595: 1-35.

Vassiliev L.S. 2013. Climate. In: Boyarsky P.V. (Ed. in chief) The

Franz-Josef Land. Moscow: Paulsen. Pp. 491 - 496. (In Russian)

Zelentsov NI. 2007. The Fauna of Chironomids (Diptera, Chironomidae) of Novaya Zemlya and Severnaya Zemlya Archipelagoes. Biology of Inland Waters 4:15-19.

Editorial responsibility: Torkild Bakken.

This article is open-access and distributed under the terms of the Creative Commons Attribution-Noncommercial 3.0 Unported License (http://creativecommons.org/licenses/by-nc/3.0/). This permits all non-commercial use, distribution, and reproduction in any medium, provided the original work is properly cited. 